\title{
Revision and new data on the Coniacian ammonite genus Hemitissotia in the Iberian Peninsula (Spain and Portugal)
}

\author{
Fernando Barroso-Barcenilla • Pedro Miguel Callapez • \\ Manuel Segura
}

Received: 3 February 2012/ Accepted: 16 July 2012/Published online: 2 September 2012

(C) Springer-Verlag 2012

\begin{abstract}
The types of the species of the Coniacian ammonite genus Hemitissotia Peron, 1897, identified in the Iberian Peninsula (Spain and Portugal), which are currently held in the Wiedmann (Universität Tübingen, Germany) and Choffat (Instituto Geológico e Mineiro, Portugal) collections, have been revised and refigured. New specimens of the taxa Hemitissotia ceadouroensis Choffat, 1898, Hemitissotia celtiberica Wiedmann, 1975b, Hemitissotia turzoi Karrenberg, 1935, Hemitissotia dullai (Karrenberg 1935) and Hemitissotia lenticeratiformis Wiedmann in Wiedmann and Kauffman, 1978 have also been presented. As results, $H$. celtiberica has been considered as a junior synonym of $H$. ceadouroensis, and the lectotype of this species and the neotypes of $H$. turzoi and $H$. dullai have been designated and figured. Additionally, the geographical and stratigraphical distributions of all of these species have been determined with precision, and several phylogenetic relationships between them have been identified,
\end{abstract}

F. Barroso-Barcenilla ( $₫)$

Departamento de Paleontología, Universidad Complutense de

Madrid, 28040 Madrid, Spain

e-mail: fbarroso@geo.ucm.es

F. Barroso-Barcenilla $\cdot$ M. Segura

Grupo de Investigación IBERCRETA, Universidad de Alcalá de

Henares, 28871 Alcalá de Henares, Spain

P. M. Callapez

Departamento de Ciências da Terra, Universidade de Coimbra, 3000-272 Coimbra, Portugal

P. M. Callapez

Centro de Geofísica, Universidade de Coimbra,

3000-134 Coimbra, Portugal revealing morphologies that become progressively smaller and more depressed and ornamented (hydrodynamically less efficient), interpreted as an adaptative response to sealevel changes.

Keywords Ammonoidea - Taxonomy - Biostratigraphy · Hemitissotia · Coniacian · Iberian Peninsula - Spain · Portugal

Kurzfassung Die Typen der Arten der AmmonitenGattung Hemitissotia Peron, 1897 aus dem Coniacium der Iberischen Halbinsel (Spanien und Portugal) wurden neu bearbeitet und abgebildet. Sie befinden sich heute in den Sammlungen von Wiedmann (Universität Tübingen, Deutschland) und Choffat (Instituto Geológico e Mineiro, Portugal). Neue Exemplare von Hemitissotia ceadouroensis Choffat, 1898, Hemitissotia celtiberica Wiedmann, 1975b, Hemitissotia turzoi Karrenberg, 1935, Hemitissotia dullai (Karrenberg 1935) und Hemitissotia lenticeratiformis Wiedmann in Wiedmann and Kauffmann, 1978, werden ebenfalls dargestellt. Dabei zeigt sich, dass $H$. celtiberica ein jüngeres Synonym von $H$. ceadouroensis ist. Der Lectotyp dieser Arten sowie die Neotypen von $H$. turzoi und $H$. dullai werden definiert und abgebildet. Die geographische und stratigraphische Verbreitung der erwähnten Arten werden detailliert dargestellt, wie auch die phylogenetischen Beziehungen. Sie weisen eine zunehmend kleinere, flachere und stärker verzierte Morphologie auf, was hydrodynamisch weniger effizient ist und scheinbare eine Anpassung an Änderungen des Meeresspiegels darstellen.

Schlüsselwörter Ammonoidea - Taxonomie . Biostratigraphie · Hemitissotia $\cdot$ Coniac $\cdot$ Iberische Halbinsel $\cdot$ Spanien $\cdot$ Portugal 


\section{Introduction}

Marked Late Cretaceous sea-level changes have been widely recorded in the Iberian Peninsula (especially in the Cantabrian and the Iberian ranges and the Central System, Spain, and the Beira Litoral Ranges, Portugal) by successive transgressive-regressive sequences with Boreal (from the Protoatlantic), Temperate-Warm (from the Tethys) and endemic cephalopods, which allow detailed stratigraphic settings and interregional correlations (Barroso-Barcenilla et al. 2011) and are closely related to the late Cenomanianearly Turonian and late Coniacian-early Santonian eustatic maximums (Haq et al. 1988; Hardenbol et al. 1998). Studies on the cephalopod assemblages of the late Cenomanian-early Turonian episode in these regions have been undertaken recently (Callapez 1998, 2003; Callapez and Soares 2001; Barroso-Barcenilla 2006, 2007; BarrosoBarcenilla and Goy 2007, 2009, 2010; Barroso-Barcenilla et al. 2009, 2011). In contrast, the palaeoenvironments along the Iberian Peninsula of the late Coniacian-early Santonian episode are less well understood, and previous interest has mainly focused on rudist assemblages and facies of shallow carbonate platforms (Gil et al. 2009).

After some approaches to the cephalopod assemblages of the latter episode (Gil et al. 2008; Barroso-Barcenilla et al. 2010; García-Hidalgo et al. 2012), this work presents the first concise and joint revision of the Iberian species of the Coniacian ammonite genus Hemitissotia and provides new data and conclusions concerning the taxonomy, distribution and evolution of this important cephalopod group of Western Tethys. This research is based not only on the type and classic material held at the Institut und Museum für Geologie und Paläontologie der Universität Tübingen, Germany, and the Museu do Instituto Geológico e Mineiro de Lisboa, Portugal, but also on new specimens recently collected in the sections of Turzo (type locality of $H$. lenticeratiformis and of the main part of the types of H. turzoi and $H$. dullai) and Nidáguila in the southeastern Cantabrian Ranges; of Cuevas de San Clemente, Contreras and Cervera-Hortezuelos (type locality of $H$. celtiberica) in the northwestern Iberian Ranges; of Castroserracín and Castrojimeno in the northeastern Central System, Spain; and of Picoto-Seadouro (type locality of $H$. ceadouroensis) in the western Beira Litoral Ranges, Portugal (Fig. 1a-f).

The genus Hemitissotia stands out as one of the most useful ammonoid groups for the Upper Cretaceous of the Iberian Peninsula, where numerous species have been described (in fact, this group will be always linked to the names of Herbert Karrenberg, Jost Wiedmann and Paul Choffat), and it has been considered a fine biostratigraphic marker for the upper Coniacian. A review of its occurrence outside the Iberian Peninsula shows that Hemitissotia is also one of the most relevant genera of the derived
Pseudotissotiidae, represented by characteristic forms of Tethyan keeled ammonites. The present knowledge about this group reveals a wide palaeobiogeographic distribution in a time span that ranges from the late Turonian to the early Santonian. The Iberian species of Hemitissotia also closely resemble some contemporary North African taxa, thus suggesting strong Tethyan faunal affinities and the prospect that future attempts at interregional correlations will be promising.

\section{Historical background}

From the end of the nineteenth and the beginning of the twentieth centuries, numerous cephalopods were collected and described from the Upper Cretaceous of the Iberian Peninsula (among them those by Mallada 1875-1891, 1891, 1892, 1904 in Spain, and by Choffat 1886, 1898, 1900, 1901-1902 in Portugal), some of them belonging to the Coniacian genus Hemitissotia Peron, 1897. Among the first systematic analyses concerning this group in Spain, that of Karrenberg (1935) was the most outstanding. This author described Hemitissotia cf. galeppei Pervinquière, 1907, Hemitissotia turzoi Karrenberg, 1935, Plesiotissotia dullai Karrenberg, 1935, Plesiotissotia dullai var. plana Karrenberg, 1935 (= H. turzoi) and Plesiotissotia cantabria Karrenberg, 1935 (= H. turzoi) in the Cantabrian Ranges. Ciry (1940) identified H. turzoi, P. dullai and P. cantabrica in the Cantabrian Ranges. Bataller (1950) compiled and refigured, among others, all the species of Hemitissotia described to date in Spain. After collecting and studying a large number of cephalopods from the Upper Cretaceous of Spain and Portugal, Wiedmann $(1960,1964)$ identified Hemitissotia ceadouroensis Choffat, 1898, H. cf. galleppei, H. turzoi, P. dullai and Hemitissotia lenticeratiformis n. sp. in the Cantabrian and the Iberian ranges. This author also proposed the Hemitissotia turzoi (Co-IV) and Hemitissotia lenticeratiformis $\mathrm{n}$. sp. (Co-V) zones as the uppermost of the Coniacian in the studied area. Wiedmann (1975a) cited $H$. cf. galleppei and $H$. cf. turzoi, and (1975b) proposed the new taxon Hemitissotia celtiberica in the Iberian Ranges. In the Cantabrian and the Iberian ranges, Wiedmann and Kauffman (1978) described Hemitissotia lenticeratiformis Wiedmann, 1978, for the first time and, like Wiedmann (1979a), identified H. celtiberica and H. turzoi. Martínez (1982) recognised H. turzoi in the Pyrenees. Floquet (1991) cited a significant number of representatives of Hemitissotia in the Cantabrian and the Iberian ranges, although he did not provide any figures. Santamaría-Zabala (1991, 1992, 1995) identified H. turzoi and H. dullai in the Cantabrian Ranges and proposed the Hemitissotia sp. Interval Zone (whose base is drown by the first appearance of $H$. turzoi, and including the Co-IV and Co- $\mathrm{V}$ zones of 

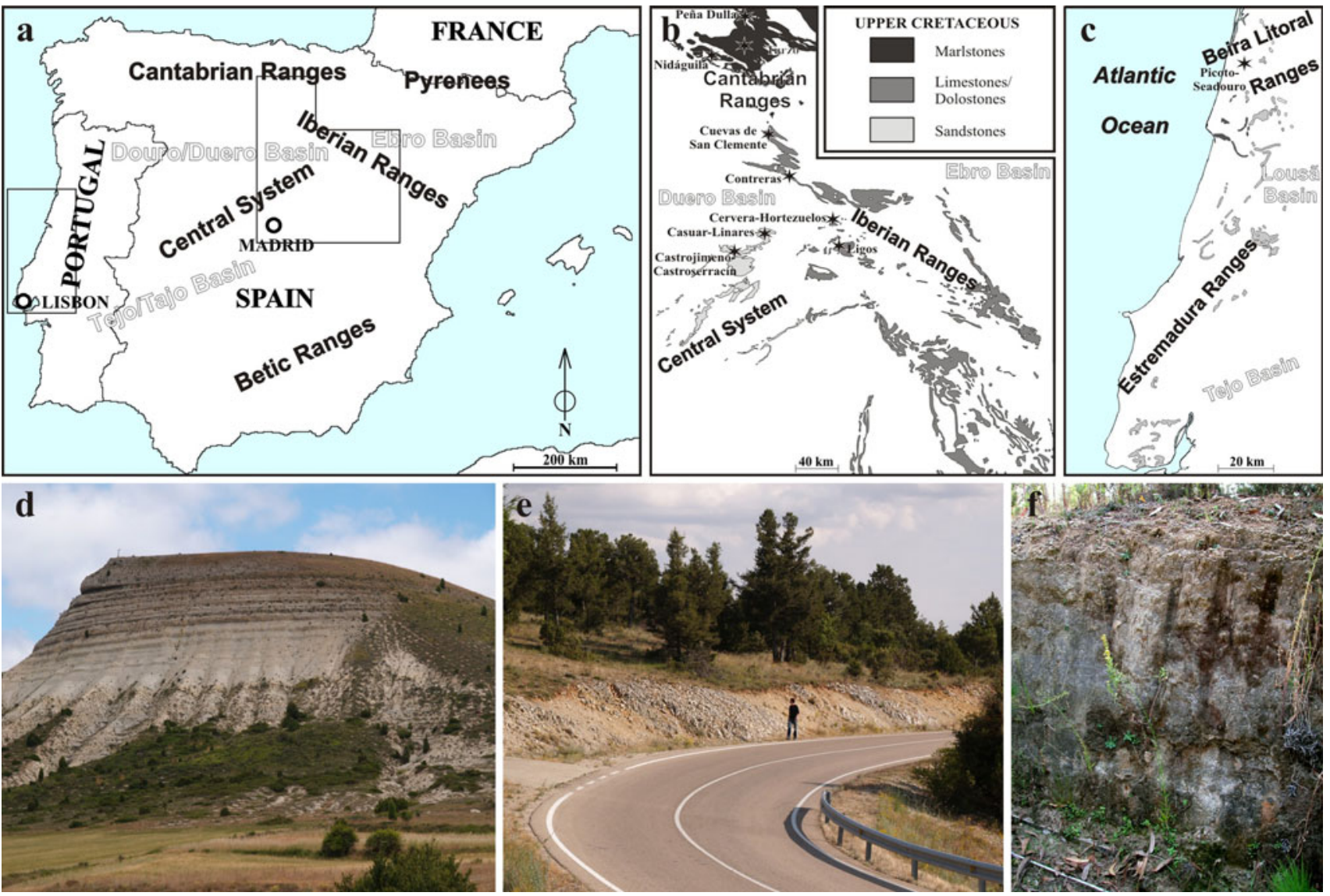

Fig. 1 Geographic and stratigraphic provenance of the Hemitissotia specimens presented in this article. a-c Geographic general location in the Iberian Peninsula (a) and stratigraphic context of the main Spanish (b) and Portuguese (c) Coniacian sections studied, including other mentioned places and the lithological distribution. d-f Photographic views of the three most representative Coniacian outcrops showing marlstones with chalky interbeds in Turzo (d), type locality of $H$. lenticeratiformis and of the main part of the types of $H$. turzoi and $H$. dullai; limestones with marly interbeds in Cervera-Hortezuelos (e), type locality of $H$. celtiberica; and sandstones with chalky interbeds in Picoto-Seadouro (f), type locality of H. ceadouroensis

interbedded marine sequences with benthic palaeofauna and a few ammonites (Hemitissotia and Hoplitoplacenticeras Paulcke, 1907) near the localities of Picoto, Seadouro and Mina. These layers of "lower Senonian" (PicotoSeadouro Sandstone with H. ceadouroensis) and "upper Senonian" (Mira Sandstone with Hoplites vari var. marotti Coquand, 1862) affinities proved to be a key to understand the regional stratigraphy (Choffat 1898, 1900). Specifically, the Coniacian age of the Picoto-Seadouro Sandstone ("Grés de Picoto-Siadouro" sensu Barbosa 1981) with Hemitissotia was first recognised by Carrington da Costa (1937). After a period without significant studies, the section was reviewed by Gutiérrez and Lauverjat (1978), Lauverjat and Pons (1978), Moron (1981) and Lauverjat (1982) by means of micropalaeontology and integrated biostratigraphy. At the same time, Picoto-Seadouro was studied by Barbosa (1981) during geological field mapping. Nevertheless, the originals of $H$. ceadouroensis are still the sole available specimens of this ammonite from the type 
locality except for a composite mould and a fragment of a body chamber recently found and described in this article.

\section{Geological setting}

The studied Spanish sections are part of a large northwestto-southeast oriented band of Upper Cretaceous materials composed by a thick carbonate sedimentary sequence (limestones and marlstones) with some interbedded terrigenous and dolostone intervals. The Coniacian of this area is well characterised in the Cantabrian and the Iberian ranges by the stratigraphic sections of Turzo and CerveraHortezuelos. In Turzo (Figs. 1d, 2), the Coniacian is recorded by several beds of biclastic limestones $(10 \mathrm{~m})$ with Forresteria petrocoriensis (Coquand 1859) and a thick interval of chalky marlstones $(>100 \mathrm{~m})$ with interbedded muddy limestones with numerous ammonoids, inoceramids, other molluses and echinoids. The upper part of this thick interval yields $H$. celtiberica, H. turzoi, $H$. dullai and $H$. lenticeratiformis and shows a gradual upwards increase in the proportion of carbonates, culminating in several beds of limestones $(10 \mathrm{~m})$ with ammonites attributed to the lower Santonian (some species of Texanites Spath, 1932). These materials have been assigned to the Margas y Calizas Margosas de Nidáguila
Formation (Floquet et al. 1982), whose stratotype was defined by Floquet (1991) some kilometres to the south. This unit was deposited in outer platform environments and provides a complete depositional trangressive-regressive sequence with a thick Transgressive Systems Tract (TST), a maximum flooding surface ( $\mathrm{mfs}$ ) located in the upper part of the thick chalky marlstones interval and a Highstand Systems Tract (HST) characterised by the increasing carbonatation of the upper part of the succession. In CerveraHortezuelos (Figs. 1e, 2), the Coniacian is represented by a thick interval of bioclastic and nodular limestones $(40 \mathrm{~m})$ with few fragments of ammonoids, echinoderms and bivalves [among them Pycnodonte vesicularis (Lamarck, 1806)]. It continues with an interval of limestones and marlstones $(10 \mathrm{~m})$ with $H$. celtiberica and $H$. turzoi, followed by a thick interval of nodular or massive limestones $(60 \mathrm{~m})$ with $P$. vesicularis and chalky sandstones $(10 \mathrm{~m})$ with scattered fragments of rudists. This is the type section of the Nidáguila Formation, and it was deposited in inner platform environments. It also constitutes a complete depositional trangressive-regressive sequence whose $\mathrm{mfs}$ is located in the interval of $10 \mathrm{~m}$ of limestones and marlstones with Hemitissotia.

The studied Portuguese exposures are part of a band of Upper Cretaceous materials of carbonate platform, marginal marine mixed and alluvial siliciclastic facies that
NNW

Turzo Section (Cantabrian Ranges, Spain)
SSE

Cervera-Hortezuelos Section (lberian Ranges, Spain)
W

Picoto-Seadouro Section (Lusitanian Ranges, Portugal)

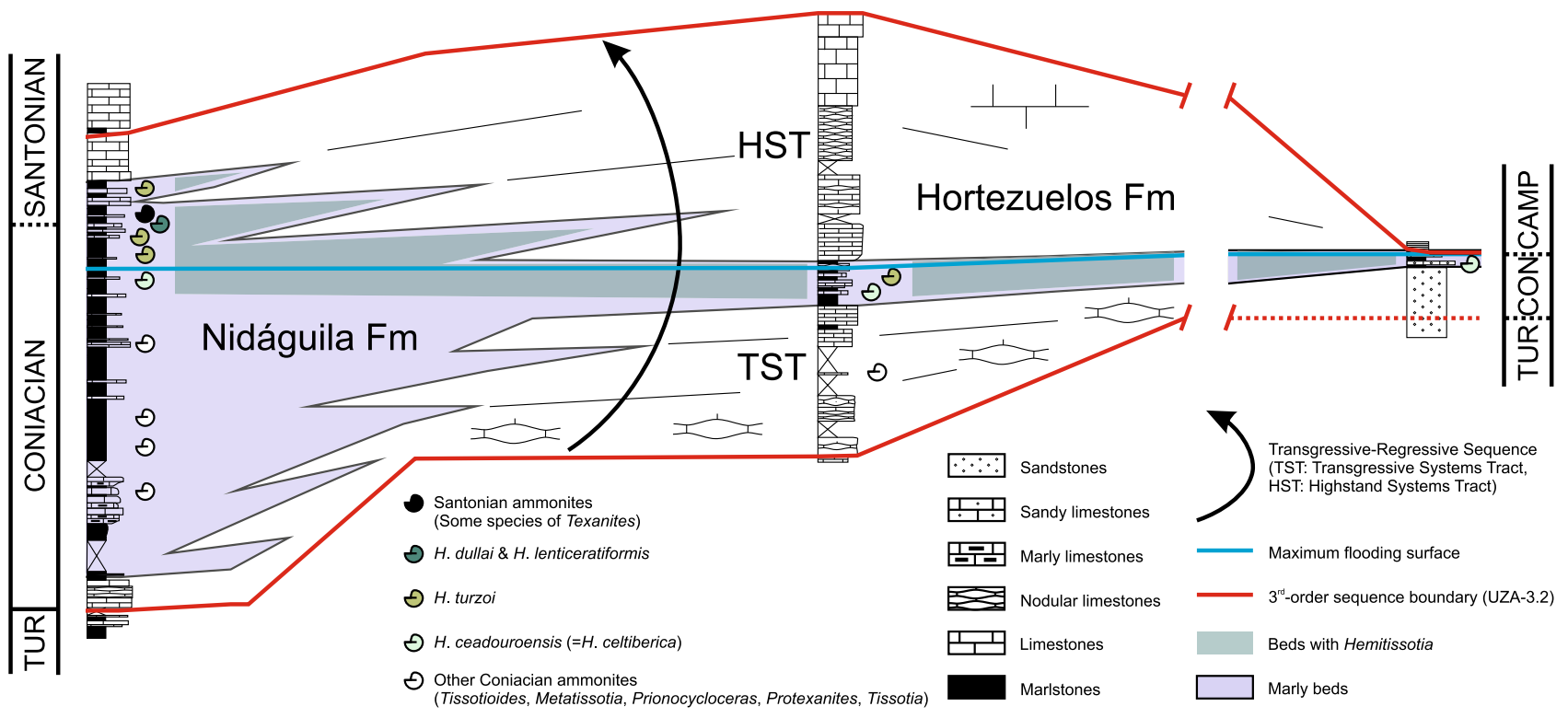

Fig. 2 Dip cross section of the upper Turonian-lower Santonian third-order depositional sequence UZA-3.2 (sensu Haq et al. 1988) in the Iberian Peninsula, showing the depositional architecture and the main cephalopod assemblages (with lateral and ventral or dorsal views of some specimens of the most representative species) relative to the reference surfaces (maximum floodings and sequence boundaries) and the system tracts (Transgressive Systems Tract and Highstand Systems Tract). Approximate locations of the represented composite sections (Turzo and Cervera-Hortezuelos, Spain, and Picoto-Seadouro, Portugal) and horizontal scale can be observed in Fig. 1a-c 
outcrops from the Beira Litoral to the Estremadura ranges. Their Coniacian cephalopods have been mainly collected from the upper part of a thick siliciclastic unit (litostratigraphically known as "Grés de Picoto-Seadouro"), starting with littoral micaceous sandstones that gradually change upwards to coarse-grained alluvial sandstones and conglomerates, and is punctuated by a single interbedded succession of marginal marine levels with marine invertebrate fossils. This short Coniacian transgressive episode is well characterised in the Picoto-Seadouro Section (Beira Litoral Ranges, Figs. 1f, 2), which yields an interesting palaeofauna with Hemitissotia and other upper Coniacian molluscs (Choffat 1898, 1900). Specifically, the figured section (the original collecting place of the most of the syntypes of Choffat) is located near the site of Mina, a small local cave with an exsurgent spring. The main fossiliferous beds are coarse-grained greyish chalky sandstones $(1.5 \mathrm{~m})$ with diverse shell concentrations of shallow water bivalves and gastropods, including mytilids, gryphaeids and glauconiids, as well as Hemitissotia and cyclolitid corals. This basal sequence is overlain by laminated greyish marls $(0.5 \mathrm{~m})$ with small carbonised plant remains and thin whitish mudstone layers, sometimes with small cerithoid gastropods. Facies and the taphonomic imprint of mollusc concentrations suggest faunal mixing in a very shallow environment of platform coastal margin as part of a maximal extent of a flooding surface.

The correlation of these three representative successions and their interpretation in the regional context of the Iberian Peninsula shows a clear relationship between the occurrence of Hemitissotia in Spain and Portugal and the mfs (Fig. 2). This fact shows that the presence of this genus was related to the transgressive maximum of the Coniacian, one important relative sea-level rise of the Upper Cretaceous (Hancock 1991, 1993; Wiese and Wilmsen 1999). Additional information and references about the geological evolution of the Spanish and Portuguese Upper Cretaceous are given in Barroso-Barcenilla et al. (2011, p. 12).

\section{The genus Hemitissotia in the Iberian Peninsula}

In this section, a detailed systematic account of the new records of the species assigned to the genus Hemitissotia Peron, 1897, is given. The terminology used for the descriptions is based on the glossary of morphological terms proposed by Barroso-Barcenilla (2008). Measurements have been made with an adjustable caliper and are given in tenths of a millimetre and in percentages of the diameter of the shell. For comments or location of refigured types (Fig. 3) and new specimens (Figs. 4, 5), the following abbreviations are used here: GPIT, Geologisches und Paläontologisches Institut der Universität Tübingen,
Germany; MIGM, Museu do Instituto Geológico e Mineiro de Lisboa, Portugal; UAH, Universidad de Alcalá de Henares, Spain; UC, Universidade de Coimbra, Portugal; UCM, Universidad Complutense de Madrid, Spain. All the specimens presented here are currently held in the Departamento de Paleontología of the UCM, the Departamento de Geología of the UAH and the Departamento de Ciências da Terra of the UC.

Superfamily Acanthoceratoidea de Grossouvre, 1894 Family Pseudotissotiidae Hyatt, 1903

Diagnosis Involute shells with feeble ornamentation. During ontogeny, the ventrolateral and siphonal tubercles tend to merge, giving rise to marked keels.

Discussion As described in detail by Barroso-Barcenilla and Goy (2007), the taxonomical status, assignment and composition of the family has changed notably. Currently, it is generally accepted that it includes the subfamilies Pseudotissottinae Hyatt, 1903, and Hourcqiinae Renz, 1982 (Wright in Kaesler 1996).

Occurrence From the upper Cenomanian to the lower Santonian.

Subfamily Pseudotissotiinae Hyatt, 1903 [Nom. transl. Wright, 1952, p. 221, ex Pseudotissotiidae Hyatt, 1903, p. 34. Hemitissotiinae Parnes, 1964, p. 13.]

Diagnosis Involute genera that usually show oxyconic morphologies with compressed whorls, tectiform or tabulate venters, flat or convex flanks and reduced ornamentations. They have wide and distant umbilical tubercles, although the last whorls are usually smooth. Some of the oldest forms of this group can preserve a globose appearance and may have ventrolateral and siphonal tubercles turning into keels in the typical subsequent taxa. Variable suture lines with a certain tendency to simplification.

Discussion As described in detail by Barroso-Barcenilla and Goy (2007), the taxonomical status, assignment and composition of the subfamily has changed notably. Currently, it is generally accepted that it includes the genera Thomasites Pervinquière, 1907, Pseudotissotia Peron, 1897, Wrightoceras Reyment, 1954, Eotissotia Barber, 1957, Donenriquoceras Wiedmann, 1960, Choffaticeras Hyatt, 1903, and Hemitissotia Peron, 1897 (Wright in Kaesler 1996).

Occurrence It ranges from upper Cenomanian to lower Santonian levels of numerous regions mainly belonging to the Tethyan Realm. On the Iberian Peninsula, the subfamily has been obtained in Spain from the base of the upper Cenomanian Spathites (Jeanrogericeras) subconciliatus Zone and in Portugal from the L level of the lower Turonian Thomasites rollandi Zone to the lower Santonian. 

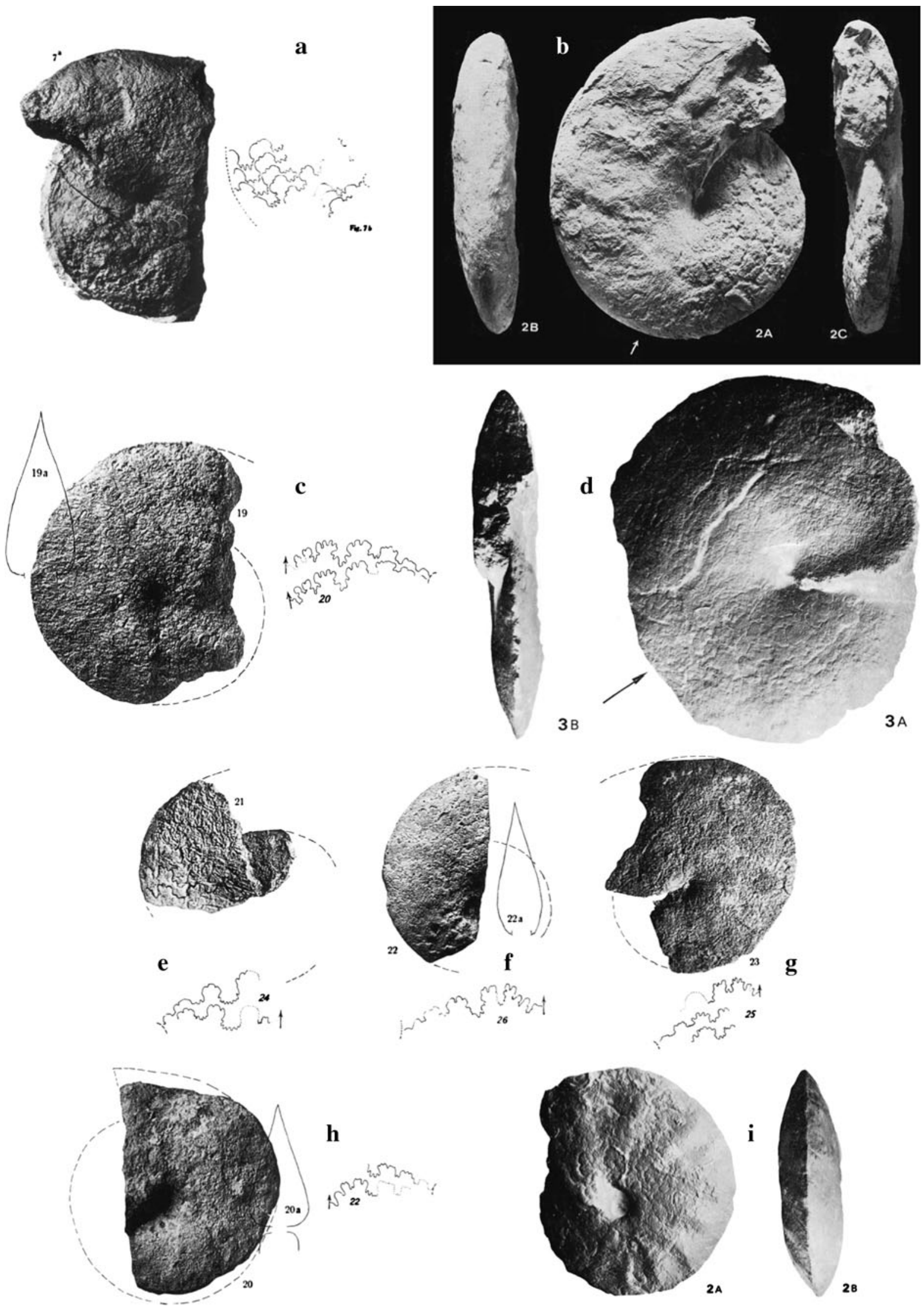
4 Fig. 3 Types of Hemitissotia from the Iberian Peninsula. a Specimen MIGML847 of Choffat (1898, pl. 20, figs. 7a-b), designated here as lectotype of $H$. ceadouroensis. b Specimen GPIT1473/3 of Wiedmann (1975b, pl. 3, fig. 2a-c), holotype of H. celtiberica (=H. ceadouroensis $)$. c Specimen of Karrenberg (1935, pl. 32, fig. 19-19a; pl. 33, fig. 20), designated by Santamaría-Zabala (1991, 1995) as lectotype of $H$. turzoi. d Specimen GPIT1456/123 of Wiedmann in Wiedmann and Kauffman (1978, pl. 22, figs. 3a-b), designated by the latter authors as hypotype of H. turzoi. e Specimen of Karrenberg (1935, pl. 32, fig. 21; pl. 33, fig. 24), syntype of Plesiotissotia dullai var. plana $(=H$. turzoi $)$. f, g Specimens of Karrenberg (1935, pl. 32, figs. 22-22a, 23; pl. 33, figs. 25-26), syntypes of Plesiotissotia cantabria $(=H$. turzoi). h Specimen of Karrenberg (1935, pl. 32, fig. 20-20a; pl. 33, fig. 22), designated by Santamaría-Zabala $(1991,1995)$ as lectotype of $H$. dullai. i Specimen GPIT 1456/122 of Wiedmann in Wiedmann and Kauffman (1978, pl. 22, figs. $2 \mathrm{a}-\mathrm{b}$ ), holotype of $H$. lenticeratiformis. Approximately $\times 3 / 5$

Genus Hemitissotia Peron, 1897 (Heterammonites Coquand, 1880 , p. 39, nom. dub., type species by original designation H. ammoniticeras; Plesiotissotia Peron, 1897, p. 79, type species by original designation P. michaleti; Allotissotia Parnes, 1964, p. 14, type species by original designation Hemitissotia galleppei Pervinquière, 1907, p. 359.)

Type-species Hemitissotia cazini Peron, 1897, p. 73, by original designation.

Diagnosis From compressed to slightly depressed ammonites with subtriangular to sublanceolate sections and sharp ventral area that can enlarge and round gradually on the mature body chamber. The first whorls may show fine ornamentation consisting of feeble umbilical tubercles and sparse and rounded ribs that tend to disappear during ontogeny. Relatively simplified suture line with five or four saddles, including a ventrolateral and a first lateral with several short indentations and the remaining three or two nearly entire.

Discussion Peron (1897) differentiated the new genera Hemitissotia and Plesiotissotia on the main basis that the former lacks ornamentation and exhibits five pseudoceratitic or slightly indented saddles per side, and the latter shows radial ribbing and has only four indented saddles per side. Nevertheless, as suggested by Wiedmann and Kauffman (1978) and Wiedmann (1979a) and confirmed by Santamaría-Zabala $(1991,1995)$, certain species of these two groups exhibit diagnostic characters of both genera, and thus Hemitissotia and Plesiotissotia can be considered synonyms. Allotissotia was defined by Parnes (1964) on the basis of the complete absence of ornamentation and slight differences in the suture line of this group regarding Hemitissotia, which does not seem enough for establishing a taxonomical group with generic rank. Heterammonites was considered as a nomen dubium by Pervinquière (1907),
Wright in Moore (1957) and Wright in Kaesler (1996), and was regarded as a synonym of Hemitissotia. Nevertheless, Chancellor et al. (1994) indicated that if the type species of this group, Heterammonites ammoniticeras Coquand, 1880 , p. 39, were included within the broad morphological variability of $H$. cazini, Heterammonites may have priority over Hemitissotia. As indicated by Parnes (1964), Chancellor et al. (1994) and Wright in Moore (1996), Hemitissotia shows little if any significant morphologic difference from the lower Turonian subgenus Choffaticeras (Leoniceras) Douvillé, 1912. The main difference between these two groups is probably the semi-entire saddles of the former compared with the more denticular saddles of the latter.

The type species of this group, H. cazini Peron, 1897, initially collected from the Coniacian of Algeria, whose lectotype was designated by Chancellor et al. (1994), reaches relatively large adult size and exhibits a compressed subogival section with a relatively rounded venter and small umbilici. H. michaleti Peron, 1897, first identified in the Coniacian of Algeria, has a compressed subogival section with imbilici of medium width and 8-10 strong bullate umbilical tubercles per whorl that give rise to the same number of wide plications. H. galleppei Pervinquière, 1907, initially collected from the Coniacian of Tunisia, whose lectotype was designated by Chancellor et al. (1994), has a compressed subogival section with scaphitoid coiling, a relatively tectiform venter and wide umbilici, and exhibits sutures with an evenly divided lateral lobe without prominent adventitious lobe. H. morreni (Coquand, 1862), first identified in the upper Turonian of Tunisia, and H. batnensis Peron, 1897, regarded as synonyms by Pervinquiére (1907) and Chancellor et al. (1994), reach relatively small adult size and have a notably inflated subtriangular section with conspicuous carina and a narrow stratigraphic distribution. This species was suggested as a wide variant of Coilopoceras Hyatt, 1903, by Robaszynski et al. (1990). H. randoi Gerth, 1961, initially collected from the lower Santonian of Austria, exhibit conspicuous ribbing and pseudoceratitic umbilical saddles. $H$. alpina Wiedmann, 1979b, first identified in the middle Coniacian (upper Turonian-lower Coniacian according Summesberger 1985) of Austria, shows a relatively wide and sublanceolate section, with an acute venter and maximum thickness slightly below the middle part of the flanks, and strongly incised suture lines with numerous elements. This species was suggested as a synonym of Coilopoceras requienianum (Orbigny 1841) by Summesberger and Kennedy (1996). H. arumaensis El-Asa'ad, 1991, initially collected from the Coniacian of Saudi Arabia and morphologically close to $H$. galleppei, reaches relatively large adult size and has compressed subogival to suboval sections with 


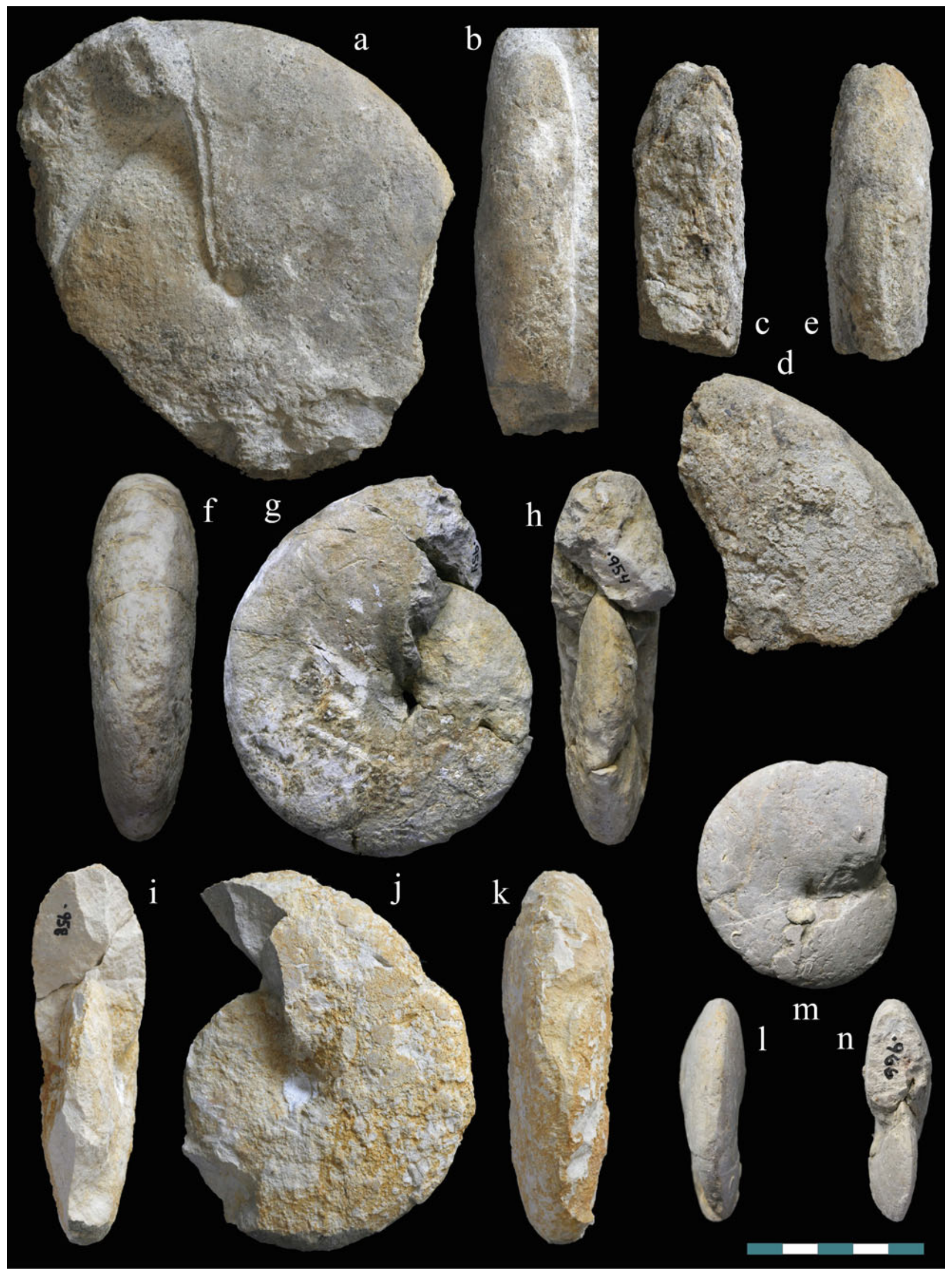


4Fig. 4 Hemitissotia ceadouroensis Choffat, 1898 (= Hemitissotia celtiberica Wiedmann, 1975b). a, b Specimen PC-S-1288, from upper Coniacian levels of Mina, near Picoto-Seadouro (type locality of H. ceadouroensis), Portugal; lateral (a) and ventral (b) views. c-e Specimen PC-S-1289 from the same stratigraphic interval of Mina; apertural (c), lateral (d) and ventral (e) views. f-h Specimen CT-S-954, from upper Coniacian levels located immediately below the Hemitissotia turzoi Zone sensu Wiedmann $(1960,1964)$ of Contreras, Spain; ventral (f), lateral (g) and apertural (h) views. i-k Specimen ST-R-958, from the same stratigraphic interval of Cervera-Hortezuelos (type locality of $H$. celtiberica), Spain; apertural (i), lateral (j) and ventral (k) views. l-n Specimen VM-R-966, from the same stratigraphic interval of Casuar-Linares, Spain; ventral (l), lateral (m) and apertural (n) views. Scale bar is $5 \mathrm{~cm}(\times 2 / 3)$

scaphitoid coiling as well as a relatively rounded venter and narrow umbilici. It exhibits a suture line with six saddles per flank, the first two of which are notched or weakly incised, and the remaining four low, broad and entire.

Occurrence Hemitissotia has been cited from the upper Turonian to the lower Santonian of southern and central Europe, northern Africa, Madagascar, Israel and Saudi Arabia. All the records of this Tethyan genus seem to be related to three third-order transgressive pulses. Specifically, the stratigraphically lower forms, $H$. morreni $(?=H$. batnesis) and $H$. alpina, although considered by some authors as possible representatives of the genus Coilopoceras, seem to be related to the upper Turonian sea-level rise of the UZA-3.1 of Haq et al. (1988). H. cazini, H. micheleti, H. galleppei, H. arumaensis and the Iberian representatives of this genus are probably related to the upper Coniacian sea-level rise of the UZA-3.2. This interval coincides with one of the strongest transgressions of the Upper Cretaceous (Gräfe and Wiedmann 1998), and it corresponds to the maximum diversification and abundance of this genus. Finally, $H$. randoi seems to be related to the lower Santonian sea-level rise of the UZA-3.3.

Hemitissotia ceadouroensis Choffat, 1898, Figs. 3a, b, $4 \mathrm{a}-\mathrm{n}$

1898 Hemitissotia ceadouroensis Choffat: 74, pl. 20, figs. 7-10.

1935 Hemitissotia cf. galeppei [sic] Pervinquière. Karrenberg: 149, pl. 32, fig. 18; pl. 33, figs. 18-19.

1937 Hemitissotia ceadouroensis Choffat. Carrington da Costa: 10.

1960 Hemitissotia cf. galleppei Pervinquière. Wiedmann: 711.

1960 Hemitissotia ceadouroensis Choffat. Wiedmann: 723.

1964 Hemitissotia cf. galleppei Pervinquière. Wiedmann: 110.

1964 Hemitissotia ceadouroensis Choffat. Wiedmann: 116. 1975a Hemitissotia cf. galleppei Pervinquière. Wiedmann: 257.

1975b Hemitissotia celtiberica Wiedmann: 145, pl. 3, fig. $2 \mathrm{a}-\mathrm{c}$.

1978 Hemitissotia ceadouroensis Choffat. Gutiérrez and Lauverjat: 107.

1978 Hemitissotia celtiberica Wiedmann, Wiedmann and Kauffman: pl. 8, fig. 3 .

1979 Hemitissotia ceadouroensis Choffat. Berthou and Lauverjat: 136.

1979a Hemitissotia celtiberica Wiedmann. Wiedmann: pl. 8, fig. 3.

1981 Hemitissotia ceadourensis [sic] Choffat. Barbosa: 32.

1981 Hemitissotia ceadouroensis Choffat. Moron: 139.

1982 Hemitissotia ceadouroensis Choffat. Lauverjat: 501.

1984 Hemitissotia ceadouroensis Choffat. Berthou: 51.

1991 Hemitissotia ceadouroensis Choffat. El-Asa'ad: 148.

Types The originals of $H$. ceadouroensis correspond to 18 specimens but, as already indicated by Choffat (1898), only 7 of them are complete and preserved enough to show the umbilicus and other diagnostic features. All of them were collected in the lower part of the PicotoSeadouro Section and are currently held in the Choffat Collection of the MIGML. Among the two original types illustrated by this author by means of photographs, only the specimen 847, figured by Choffat (p. 74, pl. 20, figs. 7a-b) and refigured herein (Fig. 3a), preserves both umbilici and is here designated as a lectotype of H. ceadouroensis. Nonetheless, it must be pointed out that the original 18 syntypes of this species show certain morphological variations in both the umbilical diameter and the body chamber section. Choffat (1898, p. 74) observed this umbilical variation, mentioning seven very involute specimens with a minute umbilicus in comparison to the ammonite of plate 20 , fig. 11 , which is quite evolute. The 18 original specimens also suggest that typical $H$. ceadouroensis has a keeled phragmocone and a rounded body chamber with a slightly ogival whorl section (Choffat 1898, pl. 20, fig. 9). Nevertheless, there is evidence of involute specimens where the body chamber is fairly compressed and slightly keeled (Choffat 1898, pl. 20, fig. 8), resembling specimens of the younger species $H$. turzoi from Spain. Because we are dealing with a condensed section and the exposure is poor, most syntypes of Picoto-Seadouro were collected at the bed surface. Thus, it seems possible that $H$. turzoi could sporadically occur in the upper part of the section, which corresponds to a marly sequence that overlies the fossiliferous sandstone beds. 


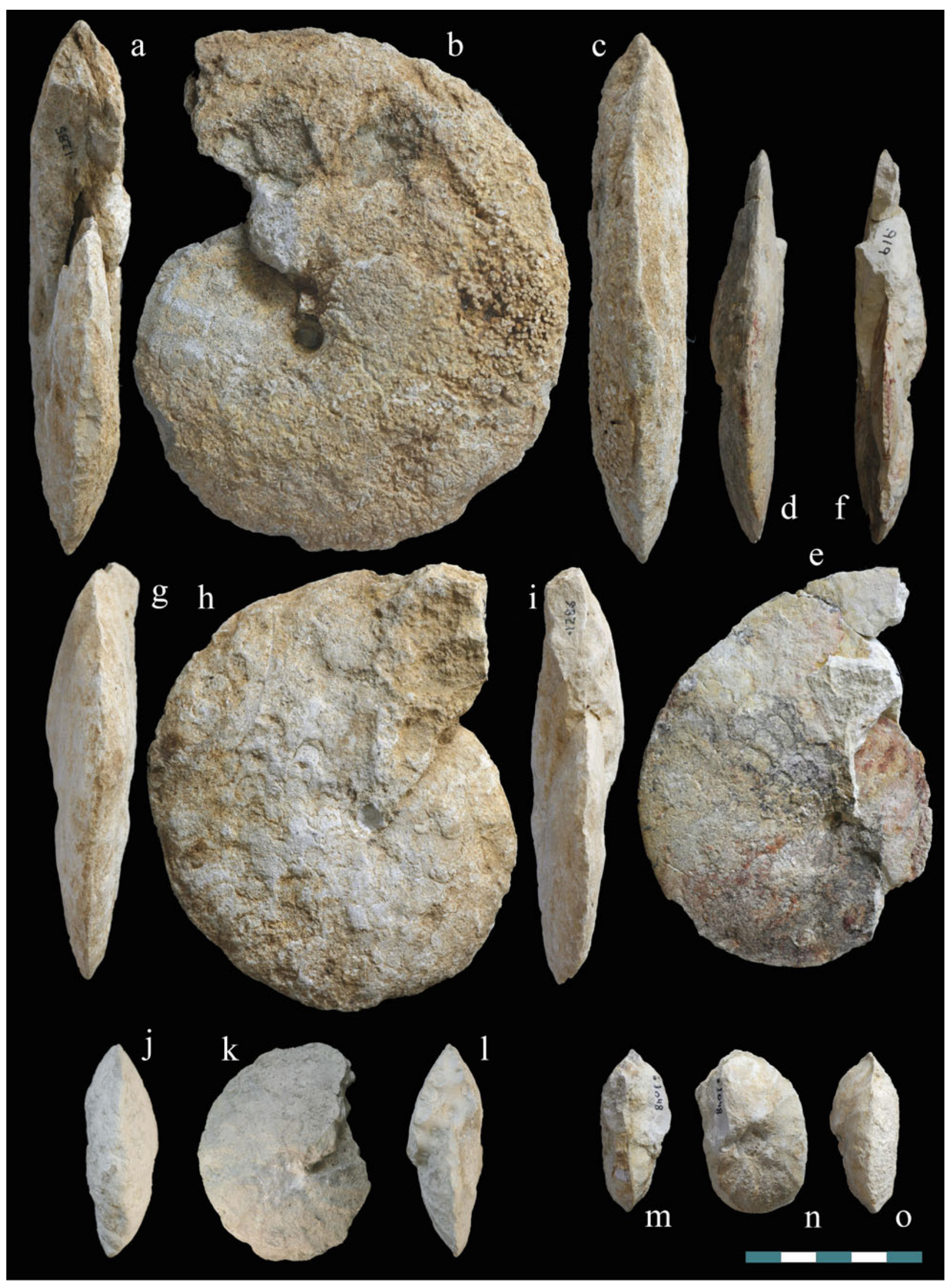


Fig. 5 a-i Hemitissotia turzoi Karrenberg, 1935. a-c Specimen R-1285 (neotype), from the uppermost Coniacian Hemitissotia turzoi Zone sensu Wiedmann (1960, 1964) of Barrio Panizares, Spain; apertural (a), lateral (b) and ventral (c) views. d-f Specimen CJ-S919, from the same stratigraphic interval of Castrojimeno, Spain; ventral (d), lateral (e) and apertural (f) views. g-i Specimen R-1286, from the same stratigraphic interval of Barrio Panizares; ventral (g), lateral (h) and apertural (i) views. j-l Hemitissotia dullai (Karrenberg, 1935); specimen NI-R-1214 (neotype) from the uppermost Coniacian Hemitissotia lenticeratiformis Zone sensu Wiedmann $(1960,1964)$ of Nidáguila, Spain; apertural (j), lateral (k) and ventral (l) views. m-o Hemitissotia lenticeratiformis Wiedmann, 1978; specimen TU-R-1048, from the uppermost Coniacian homonymous Zone sensu Wiedmann (1960, 1964) of Turzo; apertural (m), lateral (n) and ventral (o) views. Scale bar is $5 \mathrm{~cm}(\times 2 / 3)$

The holotype of $H$. celtiberica is specimen $1473 / 3$ of the Wiedmann Collection of the GPIT, obtained from the upper Coniacian at kilometre 65 of the road between Espinosa de Cervera and Hortezuelos, Spain, first figured by Wiedmann (1975b, pl. 3, fig. 2a-c), and refigured herein (Fig. 3b). Unfortunately, it was impossible to locate this specimen during the recent visit of the first author of the present article to the GPIT.

Material 35 specimens; PC-001(1288), PC-002(1289), CJ-S-920, CJ-S-923, CJ-S-925, CJ-R-930, CJ-R-931, CJR-932, CJ-R-933, CJ-R-934, CJ-R-935, CJ-R-936, CJ-R942, CJ-R-943, CJ-R-945, CJ-R-946, CJ-R-948, C1-S-953, C1-S-954，C1-R-955，C1-R-956，ST-R-958，ST-R-959, ST-R-960, ST-R-961, VM-R-965, VM-R-966, VM-R-971, LI-R-977，LI-R-978，C1-R-982，ST-R-1016，C1-R-1067, NI-R-1158 and ST-R-1287.

\begin{tabular}{llccc}
\hline Dimensions & $\mathrm{D}$ & $\mathrm{H}(\%)$ & $\mathrm{E}(\%)$ & $\mathrm{O}(\%)$ \\
\hline Range & $1310-630$ & $\begin{array}{c}710-345 \\
(58-47)\end{array}$ & $\begin{array}{c}345-165 \\
(32-20)\end{array}$ & $\begin{array}{c}150-55 \\
(14-8)\end{array}$ \\
\multirow{2}{*}{ Mean } & 965 & $500(54)$ & $255(27)$ & $100(10)$ \\
\hline
\end{tabular}

Description This species is a rather involute and compressed, of moderately large size with a slightly eccentrically coiled adult body chamber and a very narrow umbilicus. Inner whorls have convergent and smooth, flattened sides and a sharp and almost lanceloate ventral region, which enlarges considerably on the last whorl and shows a typical round section. The suture line has five large and round saddles, the first two of which show one or two short indentations; the rest are entire.

Discussion Choffat (1898) recognised the morphological proximity between $H$. ceadouroensis and Hemitissotia cazini
Peron, 1897, but pointed out certain morphological differences between both species. Pervinquière (1907) indicated that $H$. ceadouroensis could be a probable synonym of Hemitissotia morreni (Coquand, 1862), but maintained the separation of these two species. Parnes (1964) indicated that H. ceadouroensis is eccentrically coiled and resembles some specimens of $H$. galleppei with a small, nearly closed umbilicus. El-Asa'ad (1991) compared H. ceadouroensis with his new Hemitissotia arumaensis. Chancellor et al. (1994) stated that $H$. ceadouroensis exhibits a rounded mature venter and a more "tissotiid" suture than $H$. morreni.

Compared to the most similar species, in $H$. cazini the umbilici are wider and the suture lines are more indented. The same holds true for the remaining congeneric ammonites described by Peron (1897), as already indicated by Choffat (1898). H. morreni reaches smaller adult size and has a notably inflated subtriangular section with conspicuous carina and a stratigraphically lower distribution. H. galleppei has scaphitoid coiling, a tectiform venter and wider umbilici. H. arumaensis El-Asa'ad, 1991, exhibits a more depressed section and a more conspicuous carina. H. ceadouroensis shows a more compressed whorl section and a smaller umbilical width than Hemitissotia turzoi Karrenberg, 1935. In spite of these differences, both species are very similar. Although the practically continuous morphological transition between $H$. ceadouroensis and $H$. turzoi sometimes makes it difficult to distinguish both species, the latter seems to have a slightly higher and more extended vertical distribution that recommends maintaining their specific separation. Hemitissotia turzoi Karrenberg, 1935, has a completely smooth surface, a slightly more compressed and involute section, whose maximum width is close to the inner third of the flanks, an acute adult venter, and about two more lateral lobes and saddles per flank than $H$. ceadouroensis. In spite of these differences, $H$. turzoi and H. ceadouroensis are very similar, and the practically continuous morphological transition between them sometimes makes it difficult to distinguish both species (that could be considered as mere synonyms). Nonetheless, $H$. turzoi seems to have a slightly higher and more extended vertical distribution than $H$. ceadouroensis, which recommends maintaining their specific separation.

Regarding the synonymy between $H$. ceadouroensis and $H$. celtiberica, the latter form was proposed by Wiedmann (1975b) for discoidal and involute morphologies with a subogival to suboval compressed section that reaches its maximum width close to the middle part of the flanks. During juvenile stages they show an acute venter and occasionally some slight ornamentation that becomes rounded and disappears throughout ontogeny, respectively. 
Sutures are pseudoceratitic, with about three indented lateral lobes and three rounded saddles per flank. H. ceadouroensis thus seems to be somewhat more compressed and involute, reaching slightly larger adult size than $H$. celtiberica, but these differences do not seem to justify the specific separation. Therefore, H. celtiberica has been regarded here as a junior synonym of $H$. ceadouroensis, and both forms can be regarded as mere geographic varieties. Wiedmann (1975b), like Wiedmann and Kauffman (1978) and Wiedmann (Wiedmann 1979a), considered the specimens classified as $H$. cf. galeppei or $H$. galleppei Pervinquière, 1907, by Karrenberg (1935) and Wiedmann (1960, 1964, 1975a) as representatives of H. celtiberica. These specimens have thus been included here in the synonymy of $H$. ceadouroensis.

Occurrence Specimens previously classified as $H$. ceadouroensis have been reported from the upper Coniacian of Picoto-Seadouro in the Beira Litoral Ranges, Portugal, and as H. cf. galeppei or H. galleppei, or H. celtiberica in the same stratigraphic interval of Spain. In the present work, this species has been identified immediately below and in the Hemitissotia turzoi Zone sensu Wiedmann (1960, 1964) ( middle? and upper, but not uppermost, part of the Paratexanites serratomarginatus Zone sensu Gradstein et al. 2004), in the site of Mina, near PicotoSeadouro, Nidáguila, Contreras, Cervera-Hortezuelos, Ligos, Casuar-Linares and Castrojimeno-Castroserracín sections, showing that it is very abundant in the Iberian Ranges and the Central System of Spain.

Hemitissotia turzoi Karrenberg, 1935, Figs. 3c-g, 5a-i

1935 Hemitissotia turzoi Karrenberg: 150, pl. 32, fig. 19-19a; pl. 33, figs. 20-21.

1935 Plesiotissotia dullai var. plana Karrenberg: 151, pl. 32, fig. 21; pl. 33, fig. 24.

1935 Plesiotissotia cantabria Karrenberg: 152, pl. 32, figs. 22-22a, 23; pl. 33, figs. 25-26.

? 1940 Plesiotissotia cantabrica [sic] Karrenberg. Ciry: 213.

? 1940 Hemitissotia turzoi Karrenberg. Ciry: 213.

1945 Plesiotissotia cantabrica [sic] Karrenberg. Bataller: 133, fig. 743.

1945 Plesiotissotia dullai var. plana Karrenberg. Bataller: 135, fig. 745.

1945 Hemitissotia turzoi Karrenberg. Bataller: 135, fig. 746.

1949 Hemitissotia turzoi Karrenberg. Hourcq: 104, figs. 1-1a.

1949 Plesiotissotia cantabria Karrenberg. Hourcq: 104, figs. 3-3a.

cf. 1960 Hemitissotia cf. turzoi Karrenberg. Wiedmann: $711,716,722$.
1960 Hemitissotia turzoi Karrenberg. Wiedmann: 717, 719, 721, 722.

cf. 1964 Hemitissotia cf. turzoi Karrenberg. Wiedmann: 110, 113, 116.

1964 Hemitissotia turzoi Karrenberg. Wiedmann: 113-116.

cf. 1975a Hemitissotia cf. turzoi Karrenberg. Wiedmann: 257.

1977 Hemitissotia turzoi Karrenberg. El-Asa'ad: 304, pl. 24, figs. 2a-b.

1978 Hemitissotia turzoi Karrenberg. Wiedmann and Kauffman: pl. 12, figs. 3a-b.

1979a Hemitissotia turzoi Karrenberg. Wiedmann: pl. 12, figs. 3a-b.

1982 Hemitissotia turzoi Karrenberg. Martínez: 131, pl. 22 , fig. 5 .

1991 Hemitissotia turzoi Karrenberg. Santamaría-Zabala: 170 , pl. 11, fig. 7 .

cf. 1991 Hemitissotia cf. turzoi Karrenberg. SantamaríaZabala: 174

1991 Hemitissotia turzoi Karrenberg. El-Asa'ad: 143, pl. 1, figs. 1-4.

1995 Hemitissotia turzoi Karrenberg. Santamaría-Zabala: 58, pl. 5, fig. 1; fig. $1 \mathrm{k}$.

2007a Hemitissotia turzoi Karrenberg. Gallemí et al.: 98.

Types The lectotype designated by Santamaría-Zabala (1991, 1995) is the original of Karrenberg (1935, pl. 32, fig. 19-19a; pl. 33, fig. 20) from the upper Coniacian of Castrecías, Spain, refigured herein (Fig. 3c). The remaining original specimen of Karrenberg (1935, pl. 33, fig. 21) is from the upper Coniacian of Turzo, Spain. Unfortunately, as indicated by Wiedmann $(1960,1964)$, all the original specimens of Karrenberg were destroyed during World War II. The hypotype designated by Wiedmann and Kauffman (1978) and Wiedmann (1979a) is specimen $1456 / 123$ of the Wiedmann Collection of the GPIT, obtained from the uppermost Coniacian (Co-IV Zone of Wiedmann 1960, 1964) of Terradillos de Sedano, Spain, first figured by Wiedmann in Wiedmann and Kauffman (1978, pl. 22, figs. 3a-b) and refigured herein (Fig. 3d). The specimen R-1285 (Fig. 5a-c) from the upper Coniacian of Barrio Panizares is here designated as the neotype. It is currently held in the Departamento de Paleontología of the UCM.

Material 28 specimens; CJ-S-919, CJ-S-924, CJ-S-928, TU-R-988，TU-R-989，TU-R-999，TU-R-1007，TU-R1010, TU-S-1022, TU-S-1023, TU-R-1047, TU-R-1051, TU-R-1059, TU-R-1061, TU-R-1063, TU-R-1068, TU-R1069, TU-R-1070, TU-R-1071, TU-R-1072, TU-R-1073, SC-S-1118， NI-R-1157， NI-S-1220， NI-R-1221，NI-R1237, R-1285 and R-1286. 


\begin{tabular}{lllll}
\hline Dimensions & $\mathrm{D}$ & $\mathrm{H}(\%)$ & $\mathrm{E}(\%)$ & $\mathrm{O}(\%)$ \\
\hline Range & $1,600-495$ & $870-270$ & $300-115$ & $100-30$ \\
& & $(64-54)$ & $(27-15)$ & $(7-5)$ \\
Mean & 900 & $510(58)$ & $185(21)$ & $55(6)$ \\
\hline
\end{tabular}

Description Very compressed and involute species with subogival or sublanceolate whorl section, whose maximum width is close to the inner third of the flanks. Its suture lines are pseudoceratitic and variable, having five or four wide saddles per flank and deep lobes.

Discussion P. dullai var. plana and P. cantabria, only established by small differences in the suture line and whose types are refigured herein (Fig. 3e-g), can be considered as mere synonyms of $H$. turzoi, as indicated by Santamaría-Zabala $(1991,1995)$. H. turzoi is similar to the close species Hemitissotia ceadouroensis Choffat, 1898 (= Hemitissotia celtiberica Wiedmann, 1975b), as detailed above. Among the remaining species of the genus, $\mathrm{H}$. cazini Peron, 1897, exhibits a relatively similar morphology, but this species has a more rounded and less compressed whorl section compared to $H$. turzoi.

Morphologically, H. turzoi exhibits numerous features close to those characterizing Eulophoceras Hyatt, 1903, and this species, along with Hemitissotia dullai (Karrenberg, 1935), was included in this genus by Hourcq (1949). In fact, $H$. turzoi is difficult to differentiate from the lower Santonian Eulophoceras losaense Santamaría-Zabala, 1995, but the latter species exhibits juvenile ornamentation composed of tenuous ribs and more irregular suture lines.

Occurrence This species has been identified in the uppermost Coniacian Hemitissotia turzoi and Hemitissotia lenticeratiformis zones sensu Wiedmann (1960, 1964) ( $\sim$ upper part of the Paratexanites serratomarginatus Zone sensu Gradstein et al. 2004) and in the lowermost Santonian of the Cantabrian Ranges and the Pyrenees. In fact, H. turzoi has been considered an index species of the uppermost Coniacian by several authors, such as Gischler et al. (1994) and Gräfe et al. (2002). Outside Spain, specimens attributed to $H$. turzoi have been reported from Saudi Arabia by El-Asa'ad (1977, 1991). El-Asa'ad (1991) also indicated the presence of one ammonite (F-11667) from the "lower Senonian" of Morocco attributed to this species in the Sedgwick Museum of Cambridge University, UK. Hourcq (1949) described several forms very close to H. turzoi from Madagascar. In the research presented here, this species was identified in the same stratigraphic interval of the Turzo, Nidáguila, Cuevas de San Clemente and Castrojimeno-Castroserracín sections, showing that it is very abundant in the uppermost Coniacian of the
Cantabrian Ranges of Spain. However, there are less numerous records from the lowermost Santonian and from other regions of the Tethyan Realm.

Hemitissotia dullai (Karrenberg, 1935) Figs. 3h, 5j-1

1935 Plesiotissotia dullai Karrenberg: 151, pl. 32, fig. 20-20a; pl. 33, figs. 22-23.

non 1935 Plesiotissotia dullai var. plana Karrenberg: 151, pl. 32, fig. 21; pl. 33, fig. 24. [= H. turzoi]

? 1940 Plesiotissotia dullai Karrenberg. Ciry: 213, pl. 7, figs. 1-1a, 2.

1945 Plesiotissotia dullai Karrenberg. Bataller: 134, fig. 744.

non 1945 Plesiotissotia dullai var. plana Karrenberg. Bataller: 135, fig. 745.

1949 Plesiotissotia dullai Karrenberg. Hourcq: 104, figs. 2-2a.

1960 Plesiotissotia dullai Karrenberg. Wiedmann: 711, 717, 719, 721.

1964 Plesiotissotia dullai Karrenberg. Wiedmann: 110, 113-115.

1991 Hemitissotia dullai (Karrenberg). SantamaríaZabala: 174, pl. 10, fig. 3.

1995 Hemitissotia dullai (Karrenberg). SantamaríaZabala: 60, pl. 4, fig. 2; fig. $1 \mathrm{~m}$.

2007a Hemitissotia dullai (Karrenberg). Gallemí et al.: 98 , fig. $8 \mathrm{~b}$.

Types The lectotype designated by Santamaría-Zabala (1991, 1995) is the original of Karrenberg (1935, pl. 32, fig. 20-20a; pl. 33, fig. 22), from the upper Coniacian of Peña Dulla, Spain, refigured herein (Fig. 3h). The remaining original specimens of Karrenberg (1935, pl. 33, fig. 23, and non-figured) are from the upper Coniacian of Turzo and Soncillo, Spain. Unfortunately, as indicated by Wiedmann $(1960,1964)$, the original specimens of Karrenberg were destroyed during World War II. The specimen NI-R-1214 (Fig. 5j-l) from the uppermost Coniacian of Nidáguila is here designated as the neotype. It is currently held in the Departamento de Paleontología of the UCM.

Material 2 specimens; NI-R-1214 and NI-R-1229.

\begin{tabular}{lllll}
\hline Dimensions & $\mathrm{D}$ & $\mathrm{H}(\%)$ & $\mathrm{E}(\%)$ & $\mathrm{O}(\%)$ \\
\hline NI-R-1214 & 600 & $355(59)$ & $\sim 230(\sim 38)$ & $45(8)$ \\
NI-R-1229 & 760 & $450(59)$ & $\sim 350(\sim 46)$ & $85(11)$ \\
\hline
\end{tabular}

Description Small, involute, compressed and slightly inflated specimens with sublanceolate section and greatest 
whorl breadth close to the umbilical margins. Small and deep umbilici with flat, high and sloping walls and sharp umbilical shoulders. They lack adult ornamentation and have relatively simple suture lines with four saddles per flank with few incisions; the first one is divided by a deep lobe.

Discussion Ciry (1940) emended the definition of this species and included Plesiotissotia cantabria Karrenberg, 1935, and Hemitissotia turzoi Karrenberg, 1935, in its morphologic variability. On the contrary, Floquet (1991) considered $H$. dullai as a synonym of $H$. turzoi. Although there is an almost continuous morphological transition between $H$. dullai and H. turzoi (including the existence of intermediate forms, as that figured by Ciry 1940, pl. 7, figs. 1-1a), the former seems to have a wider whorl section with sharper umbilical shoulders, a smaller adult size and a shorter vertical distribution, which recommend maintaining their specific separation. Among the remaining species of the genus, only H. morreni (Coquand, 1862) exhibits a relatively close morphology, but shows a notably more inflated subtriangular section with conspicuous carina than H. dullai.

Occurrence Specimens of $H$. dullai have been collected in stratigraphic levels corresponding to the uppermost Coniacian Hemitissotia lenticeratiformis Zone sensu Wiedmann $(1960,1964)$ ( uppermost part of the Paratexanites serratomarginatus Zone sensu Gradstein et al. 2004) of the Cantabrian Ranges, Spain. In the present work, $H$. dullai has been identified in the same interval of the Nidáguila Section in the Cantabrian Ranges.

Hemitissotia lenticeratiformis Wiedmann in Wiedmann and Kauffman, 1978, Figs. 3i, 5m-o

1960 Hemitissotia lenticeratiformis n. sp. [sic] Wiedmann: 718, 722.

1964 Hemitissotia lenticeratiformis n. sp. [sic] Wiedmann: 114, 116.

1978 Hemitissotia lenticeratiformis Wiedmann in Wiedmann and Kauffman: pl. 12, figs. 2a-b.

1979a Hemitissotia lenticeratiformis Wiedmann in Wiedmann and Kauffman, Wiedmann: pl. 12, figs. 2a-b. aff. 1982 Hemitissotia lenticeratiformis Wiedmann in Wiedmann and Kauffman. Martínez: 132, pl. 23, figs. 1a-b.

aff. 2007a Hemitissotia aff. lenticeratiformis Wiedmann in Wiedmann and Kauffman. Gallemí et al.: 98.

Types The holotype is specimen $1456 / 122$ of the Wiedmann Collection of the GPIT, from the uppermost Coniacian (Co-V Zone of Wiedmann 1960, 1964) near Turzo, Spain, first figured by Wiedmann in Wiedmann and Kauffman (1978, pl. 22, figs. 2a-b) and refigured herein (Fig. 3i).
Material 2 specimens; TU-R-1048 and TU-R-1057.

\begin{tabular}{lllll}
\hline Dimensions & $\mathrm{D}$ & $\mathrm{H}(\%)$ & $\mathrm{E}(\%)$ & $\mathrm{O}(\%)$ \\
\hline TU-R-1048 & 460 & $230(50)$ & $\sim 200(\sim 43)$ & $70(15)$ \\
TU-R-1057 & - & - & $\sim 170$ & $\sim 50$ \\
\hline
\end{tabular}

Description Small, involute, compressed and slightly inflated specimens with sublanceolate section and greatest whorl breadth close to the umbilical margins. Small and deep umbilici with flat and sloping walls and sharp umbilical shoulders. They have 12 blunt and straight plications per whorl, especially marked near the ventral area, and a relatively simple suture line with four saddles per flank with few incisions.

Discussion Regarding the generic assignment of this species, Wiedmann and Kauffman (1978) and Wiedmann (1979a) stated that it exhibits intermediate characteristics between Hemitissotia and Lenticeras Gerhardt, 1897. As indicated by Wiedmann and Kauffman (1978) and Wiedmann Wiedmann (1979a), H. lenticeratiformis is close to Hemitissotia michaleti Peron, 1897, but the latter shows sharper primary and secondary ribs. Hemitissotia morreni Coquand, 1862, and its synonym Hemitissotia batnensis Peron, 1897, exhibit more inflated whorls. Hemitissotia randoi Gerth, 1961, shows different ribbing and pseudoceratitic umbilical saddles. As already indicated by its author, the specimen of Martínez (1982, pl. 23, figs. 1a-b) and maybe the non-figured of Gallemí et al. (2007a, p. 98) exhibit slightly different coiling and more tenuous and flexuous plications, and could be a representative of a different taxon.

Occurrence Specimens of $H$. lenticeratiformis have been identified in stratigraphic levels corresponding to the uppermost Coniacian homonymous Zone sensu Wiedmann (1960, 1964) of the Cantabrian Ranges, Spain, being considered the index species of this interval by several authors, such as Gischler et al. (1994) and Gräfe et al. (2002). In the research presented here, $H$. lenticeratiformis was collected in the same interval of the Turzo Section in the Cantabrian Ranges.

\section{Conclusions}

The types of the species of the Coniacian ammonite genus Hemitissotia Peron, 1897, identified in the Iberian Peninsula (Spain and Portugal), which are currently held in the Wiedmann (Universität Tübingen, Germany) and Choffat (Instituto Geológico e Mineiro, Portugal) collections, have been revised and refigured. Unfortunately, it was 
impossible to include the original specimens of the Karrenberg Collection in this study because they were destroyed during World War II. However, numerous new specimens of the taxa Hemitissotia ceadouroensis Choffat, 1900, Hemitissotia celtiberica Wiedmann, 1975b, Hemitissotia turzoi Karrenberg, 1935, Hemitissotia dullai (Karrenberg, 1935) and Hemitissotia lenticeratiformis Wiedmann in Wiedmann and Kauffman, 1978, have been collected in several Spanish (e.g., Turzo, type locality of $H$. lenticeratiformis and of the main part of the types of H. turzoi and H. dullai, and CerveraHortezuelos, type locality of $H$. celtiberica) and Portuguese (e.g., Picoto-Seadouro, type locality of $H$. ceadouroensis) sections and are presented here. $H$. celtiberica has been considered as a junior synonym of $H$. ceadouroensis, and the lectotype of this species, and the neotypes of $H$. turzoi and $H$. dullai have been designated and figured.

The stratigraphical and geographical distribution of Hemitissotia in this region has been determined with precision; it occurs in the upper Coniacian ( upper part of the Paratexanites serratomarginatus Zone) with sporadic records in the lowermost Santonian. Specifically, $H$. ceadouroensis $(=H$. celtiberica) was identified immediately below and in the Hemitissotia turzoi Zone sensu Wiedmann $(1960,1964)(\sim$ middle? and upper, but not uppermost, part of the Paratexanites serratomarginatus Zone), being very abundant in the Iberian Ranges and the Central System of Spain and less common in the Beira Litoral Ranges of Portugal. H. turzoi has been collected in the Hemitissotia turzoi and Hemitissotia lenticeratiformis zones sensu Wiedmann $(1960,1964)$ ( upper part of the Paratexanites serratomarginatus Zone) and in the lowermost Santonian, being very abundant in the Cantabrian Ranges of Spain. H. dullai has been identified in the Hemitissotia lenticeratiformis Zone sensu Wiedmann (1960, 1964) ( uppermost part of the Paratexanites serratomarginatus Zone) of the Cantabrian Ranges of Spain, and $H$. lenticeratiformis has been identified in the same stratigraphic and geographic intervals. The records of $\mathrm{H}$. ceadouroensis and the acme of $H$. turzoi seem to be related to the maximum flooding surface ( $\mathrm{mfs}$ ) of the third-order sequence UZA-3.2 (sensu Haq et al. 1988), whereas the records of $H$. dullai and H. lenticeratiformis seem to be related to the Highstand Systems Tract (HST) of the same cycle. In terms of the phylogeny of the group, one possible evolutionary lineage joining $H$. turzoi with $H$. dullai and $H$. lenticeratiformis has been identified, revealing morphologies that become progressively smaller and more depressed and ornamented (hydrodynamically less efficient ammonites: Chamberlain 1980; Westermann 1996). These morphological changes seem to be adaptative responses to the sea-level oscillations (ecophenotypic variations: Wilmsen and Mosavinia, 2011), specifically to the shallowing related to the change from the maximum flooding to the HST.
Acknowledgments Authors appreciate the help offered by Prof. Dr. Philipe Havlik from the Institut und Museum für Geologie und Paläontologie der Universität Tübingen, Germany, and by Prof. Dr. Miguel Magalhães Ramalho from the Museu do Instituto Geológico e Mineiro de Lisboa, Portugal, with the studies of the types held in their respective institutions, and by D. Florencio Aparicio Alonso, from Hoyos del Tozo, Spain, with the donation of several specimens he collected. We also recognise the collaboration of Prof. Dr. José García-Hidalgo and Prof. Dr. Javier Gil from the Universidad de Alcalá de Henares, Spain, and Ricardo Paredes from the Universidade de Coimbra, Portugal, with the field work, and the useful comments of Prof. Dr. Ricardo Martínez from the Universitat Autònoma de Barcelona, Spain, and Prof. Dr. Markus Wilmsen from the Universität Würzburg, Germany, as reviewers of the original manuscript. Authors thank the Centro de Geofísica da Universidade de Coimbra (FCTFoundation of Science and Technology), Portugal, for its support. This study was carried out within the projects PEII11-0237-7926 of the Junta de Castilla-La Mancha, and CGL2009-12008 and CGL2011-25894 of the Ministerio de Ciencia e Innovación, Spain.

\section{References}

Barber, W. 1957. Lower Turonian ammonites from north-eastern Nigeria. Geological Survey of Nigeria, Bulletin 26: 1-87.

Barbosa, B.P. 1981. Carta Geológica de Portugal (1:50.000). Notícia explicativa da folha 16C-Vagos, 1-60. Lisboa: Serviços Geológicos de Portugal.

Barroso-Barcenilla, F. 2006. Cefalópodos del Cenomaniense superior $y$ del Turoniense inferior en el Surco Ibérico, España, 1-603. Universidad Complutense de Madrid (PhD thesis).

Barroso-Barcenilla, F. 2007. Revision and new data of the ammonite family Acanthoceratidae de Grossouvre, 1894, from the lower Turonian of the Iberian Trough, Spain. Palaeontographica, Abteilung A 280: 123-163.

Barroso-Barcenilla, F. 2008. Revisión de la terminología aplicada a los nautiloideos y ammonoideos en español. Boletín de la Real Sociedad Española de Historia Natural, Sección Geológica 102: $121-145$

Barroso-Barcenilla, F., and A. Goy. 2007. Revision and new data of the ammonite family Pseudotissotiidae in the Iberian Trough, Spain. Geobios 40: 455-487.

Barroso-Barcenilla, F., and A. Goy. 2009. The ammonite genera Fagesia and Neoptychites (family Vascoceratidae) in the Iberian Trough, Spain. Geobios 42: 17-42.

Barroso-Barcenilla, F., and A. Goy. 2010. The ammonite genus Vascoceras Choffat, 1898 (family Vascoceratidae Douvillé, 1912) in the Iberian Trough, Spain. Palaeontographica, Abteilung A 290: 199-235.

Barroso-Barcenilla, F., A. Goy, and M. Segura. 2009. Ammonite zonation of the upper Cenomanian and lower Turonian in the Iberian Trough, Spain. Newsletters on Stratigraphy 43: 139-164.

Barroso-Barcenilla, F., J.F. García-Hidalgo, J. Gil, and M. Segura. 2010. The Coniacian-early Santonian depositional sequence in the Iberian Trough (Spain): Stratigraphic and Palaeontological frameworks. Carnets de Géologie 7: 22-23.

Barroso-Barcenilla, F., P.M. Callapez, A.F. Soares, and M. Segura. 2011. Cephalopod assemblages and depositional sequences from the upper Cenomanian and lower Turonian of the Iberian Peninsula (Spain and Portugal). Journal of Iberian Geology 37: 9-28.

Bataller, J.R. 1950. Sinopsis de las especies nuevas del Cretácico de España, Mollusca. Anales de la Escuela de Peritos Agrícolas 6: $1-186$.

Berthou, P.Y. 1984. Répartition Stratigraphique actualisée des principaux foraminifères benthiques du Crétacé moyen et supérieur du Bassin Occidental Portugais. Benthos 83: 45-54. 
Berthou, P.Y., and J. Lauverjat. 1979. Essai de synthèse paléogéographique du du Bassin Occidental Portugais au cours du Crétacé supérieur. Ciencias da Terra 5: 121-144.

Callapez, P.M. 1998. Estratigrafia e Paleobiologia do CenomanianoTuroniano: $O$ significado do eixo da Nazaré-Leiria-Pombal, 1-491. Universidade de Coimbra ( $\mathrm{PhD}$ thesis).

Callapez, P.M. 2003. The Cenomanian-Turonian transition in West Central Portugal: ammonites and biostratigraphy. Ciências $d a$ Terra 15: 53-70.

Callapez, P.M., and A.F. Soares. 2001. Fósseis de Portugal: Amonóides do Cretácico Superior (Cenomaniano-Turoniano), 1-106. Coimbra: Museu Mineralógico e Geológico da Universidade de Coimbra.

Carrington da Costa, J. 1937. O Neocretácico da Beira Litoral. Publicações do Museu e Laboratório Mineralógico e Geológico da Faculdade de Ciências do Porto 5: 1-33.

Chamberlain, J.A. 1980. Hydromechanical design of fossil cephalopods. Systematic Association Special Volume 18: 289-336.

Chancellor, G.R., W.J. Kennedy, and J. Hancock. 1994. Turonian ammonite faunas from Central Tunisia. Special Papers in Palaeontology 50: 1-118.

Choffat, P. 1886. Recueil d'études paléontologiques sur la Faune Crétacique du Portugal, 1, 1-40. Lisboa: Section des Travaux Géologiques du Portugal.

Choffat, P. 1898. Recueil d'études paléontologiques sur la Faune Crétacique du Portugal, 2, 1-45. Lisboa: Section des Travaux Géologiques du Portugal.

Choffat, P. 1900. Recueil de monographies stratigraphiques sur le Système Crétacique du Portugal, 2, 1-287. Lisboa: Direction des Services Géologiques du Portugal.

Choffat, P. 1901-02. Recueil d'études paléontologiques sur la Faune Crétacique du Portugal, 3-4. Lisboa: Direction des Services Géologiques du Portugal.

Ciry, R. 1940. Étude géologique d'une partie des provinces de Burgos, Palencia, León et Santander. Bulletin de la Société d'Histoire Naturelle de Toulouse 74: 1-513.

Coquand, H. 1859. Synopsis des animaux et des végétaux fossiles observés dans la Formation crétacé du sud-ouest de la France. Bulletin de la Société Géologique de France 2(16): 945-1023.

Coquand, H. 1862. Géologie et paléontologie de la région sud de la Province de Constantine. Mémoires de la Société d'Émulation de la Provence 2: 1-341.

Coquand, H. 1880. Études supplémentaires sur la paléontologie algérienne faisant suite à la description géologique et paléontologique de la région sud de la province de Constantine. Bulletin de l'Académie d'Hippone 15: 1-449.

de Grossouvre, A. 1894. Recherches sur la craie supérieure, 2, 1-264. Paris: Mémoires du Service de la Carte Géologique Détaillée de la France.

Douvillé, H. 1912. Évolution et classification des Pulchelliidés. Bulletin de la Société Géologique de France 4(11): 285-320.

El-Asa'ad, G.M.A. 1977. A contribution to the Geology of the Aruma Formation in Central Saudi Arabia, 1-384. University of Mansoura ( $\mathrm{PhD}$ thesis).

El-Asa'ad, G.M.A. 1991. Late Cretaceous ammonites from Central Saudi Arabia. Journal of the King Saud University 3: 135-158.

Floquet, M. 1991. La plate-forme nord-castillane au Crétacé Supérieur (Espagne). Mémoires Géologiques de l'Université de Dijon 14: $1-925$.

Floquet, M., A. Alonso, and A. Meléndez. 1982. El Cretácico Superior de Cameros-Castilla. In El Cretácico de España, ed. A. García, 387-456. Madrid: Universidad Complutense de Madrid.

Gallemí, J., G. López, R. Martínez, and J.M. Pons. 2007a. Macrofauna of the Villamartín Section: Coniacian/Santonian boundary,
North Castilian Platform, Burgos, Spain. Cretaceous Research 28: 93-107.

Gallemí, J., G. López, R. Martínez, and J.M. Pons. 2007b. Macrofauna of the Cantera de Margas section, Olazagutia (Coniacian/ Santonian boundary, Navarro-Cantabrian Basin, N Spain). Cretaceous Research 28: 5-17.

García-Hidalgo, J.F., F. Barroso-Barcenilla, J. Gil, R. Martínez, J.M. Pons, and M. Segura. 2012. Stratal, sedimentary and faunal relationships in the Coniacian 3rd-order sequence of the Iberian Basin (Spain). Cretaceous Research 34: 268-283.

Gerhardt, K. 1897. Beitrag zur Kenntniss der Kreideformation in Venezuela und Peru. Neues Jahrbuch für Mineralogie, Geologie und Paläontologie 11: 65-117.

Gerth, H. 1961. Neue Ammonitenfunde in den Gosauschichten der Gosau und ihre stratigraphische Bedeutung. Neues Jahrbuch für Geologie und Paläontologie Abhandlungen 112: 119-142.

Gil, J., F. Barroso-Barcenilla, J.M. Pons, M. Segura, and J.F. GarcíaHidalgo. 2008. Depositional architecture and fauna (Ammonoidea and Hippuritoida) in the Coniacian of the Iberian Ranges (Spain). Schriftenreihe der Deutschen Gesellschaft für Geowissenschaften 58: 112.

Gil, J., J.M. Pons, and M. Segura. 2009. Succession of rudistid lithosomes along the western coastal margin of the Iberian Trough (Coniacian, Castrojimeno section, central Spain). Facies 55: 523-539.

Gischler, E., K.U. Gräfe, and J. Wiedmann. 1994. The upper Cretaceous Lacazina limestone in the Basco-Cantabrian and Iberian Troughs of northern Spain: cold-water grain associations in warm-water environments. Facies 30: 209-246.

Gradstein, F.M., J.G. Ogg, and A.G. Smith (eds.). 2004. A geologic time scale 2004, 1-589. Cambridge: Cambridge University Press.

Gräfe, K.U., and J. Wiedmann. 1993. Sequence stratigraphy in the Upper Cretaceous of the Basco-Cantabrian Basin (northern Spain). Geologische Rundschau 82: 327-361.

Gräfe, K.U., and J. Wiedmann. 1998. Sequence stratigraphy on a carbonate ramp: The late Cretaceous Basco-Cantabrian Basin (northern Spain). SEPM Special Publication 60: 333-341.

Gräfe, K.U., M. Floquet, and I. Rosales. 2002. Late Cretaceous of the Basque-Cantabrian Basin. In The geology of Spain, ed. W. Gibbons, and M.T. Moreno, 281-284. London: The Geological Society.

Gutiérrez, G., and J. Lauverjat. 1978. Les Charophytes du Sénonien superieur de la Beira Litoral (Portugal). 103 Congrès National des Sociétés Savantes 2:105-117.

Hancock, J.M. 1991. Ammonite scales for the Cretaceous System. Cretaceous Research 12: 259-291.

Hancock, J.M. 1993. Sea-level changes around the CenomanianTuronian boundary. Cretaceous Research 14: 553-562.

Haq, B.U., J. Hardenbol, and P.R. Vail. 1988. Mesozoic and Cenozoic chronostratigraphy and eustatic cycles. SEPM Special Publication 42: 71-108.

Hardenbol, J., J. Thierry, M.B. Farley, T. Jacquin, P.C. de Graciansky, and P.R. Vail. 1998. Mesozoic and Cenozoic sequence chronostratigraphic framework of European basins, Chart 1. SEPM Special Publication 60: Appendix.

Hourcq, V. 1949. Paléontologie de Madagascar, 28. Sur quelques ammonites du Sénonien. Annales de Paléontologie 35: 10-31.

Hyatt, A. 1903. Pseudoceratites of the Cretaceous. United States Geological Survey Monograph 44: 1-351.

Karrenberg, M. 1935. Ammoniten aus der Nordspanischen Oberkreide. Palaeontographica, Abteilung A 82: 125-161.

Küchler, T. 1998. Upper Cretaceous of the Barranca (Navarra, northern Spain); integrated litho-, bio-, and event stratigraphy, 1. Acta Geologica Polonica 48: 157-236. 
Küchler, T., and G. Ernst. 1989. Integrated biostratigraphy of the Turonian-Coniacian transition interval in northern Spain with comparison to NW-Germany. In Cretaceous of Western Tethys, ed. J. Wiedmann, 161-190. Stuttgart: Schweitzerbart'sche Verlagsbuchhandlun.

Lamarck, J.B. 1806. Mémoires sur les fossiles des environs de Paris, 6. Annales du Muséum d'Histoire Naturelle 7: 53-430.

Lauverjat, J. 1982. Le Crétacé Supérieur dans le Nord du Bassin Occidental Portugais, 1-716. Université Pierre et Marie Curie ( $\mathrm{PhD}$ thesis).

Lauverjat, J., and D. Pons. 1978. Le gisement Sénonien d'Esgueira (Portugal): stratigraphie et flore fossile. 103 Congrès National des Sociétés Savantes 2:119-137.

Mallada, L. 1875-1891. Sinopsis de las especies fósiles que se han encontrado en España, 2-17. Madrid: Boletín de la Comisión del Mapa Geológico de España.

Mallada, L. 1891. Sinopsis Paleontológica de España, Sistema Cretáceo. Madrid: Boletín de la Comisión del Mapa Geológico de España 17 (1890): pls.7-12.

Mallada, L. 1892. Catálogo General de las especies fósiles encontradas en España, 1-253. Madrid: Boletín de la Comisión del Mapa Geológico de España 18 (1891).

Mallada, L. 1904. Explicación del Mapa Geológico de España, 5, 1-519. Madrid: Memoria de la Comisión del Mapa Geológico de España.

Martínez, R. 1982. Ammonoideos cretácicos del Prepirineo de la provincia de Lleida. Publicaciones de Geología de la Universidad de Barcelona 17: 1-196.

Martínez, R., M.A. Lamolda, A. Gorostidi, G. López, and R. Santamaría-Zabala. 1996. Bioestratigrafía integrada del Cretácico Superior (Cenomaniense Superior-Santoniense) de la región Vascocantábrica. Revista Española de Paleontología, Número Extraordinario:160-171.

Moron, J. 1981. Étude Paléobotanique et Palynologique du Crétacé supérieur du Bassin Occidental Portugais au Nord de l'accident de Nazaré (Portugal), 1-287. Université Pierre et Marie Curie ( $\mathrm{PhD}$ thesis).

Orbigny, A.d'. 1841. Paléontologie Française, Description des Mollusques et Rayonnés Fossiles, Térrains Crétacés, Céphalopodes, 1, 121-430. Paris: Masson.

Parnes, A. 1964. Coniacian ammonites from the Negev (Souther Israel). Bulletin of the Geological Survey of Israel 39:42.

Paulcke, W. 1907. Die Cephalopoden der oberen Kreide Süpatagoniens. Berichte der Naturforschenden Gesellschaft zu Freiburg 15: $167-248$.

Peron, A. 1897. Les ammonites du Crétacé Superieur de 1'Algérie. Mémoires de la Société Géologique de France 17: 25-88.

Pervinquière, L. 1907. Études de paléontologie tunisienne, 1, 1-438. Paris: Carte Géologique de la Tunisie.

Renz, O. 1982. The Cretaceous ammonites of Venezuela, 1-132. Caracas: Maraven.

Reyment, R.A. 1954. New Turonian (Cretaceous) ammonite genera from Nigeria. Colonial Geology and Mineral Resources 4: 149-164.

Robaszynski, F., F. Caron, C. Dupuis, F. Amédro, J.M. González Donoso, D. Linares, J. Hardenbol, S. Gartner, F. Calandra, and R. Deloffre. 1990. A tentative integrated stratigraphy in the Turonian of Central Tunisia: formations, zones and sequential stratigraphy in the Kalaat Senan area. Bulletin des Centres de Recherches (Exploration-Production) ELF-Aquitaine 14: 213-384.

Santamaría-Zabala, R. 1991. Ammonoideos del Cretácico Superior de la Plataforma Nord-Castellana y parte de la Cuenca NavarroCántabra, 1-375. Paleontología y Bioestratigrafía. Universidad de Barcelona ( $\mathrm{PhD}$ thesis).
Santamaría-Zabala, R. 1992. Los ammonoideos del Cenomaniense Superior al Santoniense de la Plataforma Nord-Castellana y la Cuenca Navarro-Cántabra, 1. Treballs del Museu de Geologia de Barcelona 2: 171-268.

Santamaría-Zabala, R. 1995. Los ammonoideos del Cenomaniense superior al Santoniense de la Plataforma Nord-Castellana y la Cuenca Navarro-Cántabra, 2. Treballs del Museu de Geologia de Barcelona 4: 15-131.

Spath, L.F. 1932. A monograph of the Ammonoidea of the Gault, 9. The Palaeontographical Society, Monograph 379-410.

Summesberger, H. 1985. Ammonite zonation of the Gosau Group (Upper Cretaceous, Austria). Annalen des Naturhistorischen Museums in Wien 87: 145-166.

Summesberger, H., and W.J. Kennedy. 1996. Turonian ammonites from the Gosau Group (Upper Cretaceous; Northern Alps; Austria) with a revision of Barroisiceras haberfellneri (Hauer, 1866). Beiträge zur Paläontologie 21: 105-177.

Westermann, G.E.G. 1996. Ammonoid life and habitat. Topics in Geobiology 13: 607-707.

Wiedmann, J. 1960. Le Crétacé supérieur de l'Espagne et du Portugal et ses Céphalopodes. In Colloque sur le Crétacé Supérieur Français, ed. Roger, J., 709-764. Dijon: Comptes Rendus du 84 Congrès National des Sociétés Savantes.

Wiedmann, J. 1964. Le Crétacé supérieur de l'Espagne et du Portugal et ses Céphalopodes. Estudios Geológicos 20: 107-148.

Wiedmann, J. 1975a. El Cretácico Superior del Picofrentes (Soria), Cadenas Celtibéricas (España). Boletín Geológico y Minero 86: 252-261.

Wiedmann, J. 1975b. Subdivisiones y precisiones bio-estratigráficas en el Cretácico Superior de las Cadenas Celtibéricas. In Reunión de campo sobre el Cretácico de la Provincia de Cuenca, España, ed. B. Meléndez, and F. Meléndez, 135-153. Cuenca: Acta del Primer Symposium sobre el Cretácico de la Cordillera Ibérica.

Wiedmann, J. 1979a. Itineraire géologique à travers le Crétacè moyen des Châines Vascogotiques et Celtibériques (Espagne du Nord). Cuadernos de Geología Ibérica 5: 127-214.

Wiedmann, J. 1979b. Ammonites. Mitteilungen der Bayerischen Staatssammlung für Paläontologie und Historische Geologie 19: 27-92.

Wiedmann, J., and G. Kauffman. 1978. Mid-Cretaceous biostratigraphy of northern Spain. Annales du Muséum d'Histoire Naturelle de Nice 4, iii.1-iii.34.

Wiese, F. 1997. Das Turon und Unter-Coniac im Nordkantabrischen Becken (Proviz Kantabrien, Nordspanien): Faziesentwicklung, Bio-, Event- und Sequenzstratigraphie. Berliner Geowissenschaftliche Abhandlungen E24: 1-131.

Wiese, F. 2000. Coniacian ammonites from the North Cantabrian Basin (Cantabria, northern Spain). Acta Geologica Polonica 50: 141-152.

Wiese, F., and M. Wilmsen. 1999. Sequence stratigraphy in the Cenomanian to Campanian of the North Cantabrian Basin (Cantabria, N-Spain). Neues Jahrbuch für Geologie und Paläontologie Abhandlungen 212: 131-173.

Wilmsen, M., and A. Mosavinia. 2011. Phenotypic plasticity and taxonomy of Schloenbachia varians (J. Sowerby, 1817) (Cretaceous Ammonoidea). Paläontologische Zeitschrift 85: 169-184.

Wright, C.W. 1952. A classification of the Cretaceous ammonites. Journal of Paleontology 26: 213-222.

Wright, C.W. 1957. Ammonoidea (Part L, Mollusca 4). In Treatise on invertebrate paleontology, ed. R.C. Moore, 1-490. Lawrence: Geological Society of America \& University of Kansas Press.

Wright, C.W. 1996. Cretaceous Ammonoidea (Part L, Mollusca 4). In Treatise on invertebrate paleontology, ed. R.L. Kaesler, 1-362. Lawrence: Geological Society of America \& University of Kansas Press. 